\title{
Climate Change, Salinization and High-Yield Rice Production in Coastal Bangladesh
}

\section{Susmita Dasgupta, Md. Moqbul Hossain, Mainul Huq, and David Wheeler}

\begin{abstract}
Progressive salinization of water and soil will be increasingly severe in low-lying coastal areas as climate change proceeds. Thus, understanding the economic impacts of salinity intrusion will be essential for effective adaptation planning. This paper uses econometric analysis to predict the impact of climate-induced increases in soil salinity on high-yielding-variety rice production in coastal Bangladesh. Findings indicate an output decline of 15.6 percent in nine subdistricts where soil salinity will exceed 4 deciSiemens per meter before 2050 . Without new adaptation strategies, the predicted changes will result in 7.7 and 5.6 percent losses in the Barisal and Chittagong regions, respectively.
\end{abstract}

Key Words: agriculture, climate change, coastal areas, soil salinity, rice production JEL Classification: Q11, Q24, Q54

Among the multiple vulnerabilities low-lying coastal areas face due to climate change, progressive water and soil salinization pose particularly serious threats. ${ }^{1}$ Worldwide, about 600 million people currently inhabit lowelevation coastal zones (Wheeler 2011, Center for International Earth Science

\footnotetext{
Susmita Dasgupta is Lead Environmental Economist, Development Research Group, at the World Bank. Md. Moqbul Hossain is Principal Scientific Officer at the Soil Research Development Institute, Ministry of Agriculture, Bangladesh. Mainul Huq is a consultant at the World Bank. David Wheeler is a Senior Fellow at the World Resources Institute Correspondence: Susmita Dasgupta Development Economics Research Group - Environment and Energy Unit - The World Bank - 1818 H Street - Washington DC 20433 - email sdasgupta@worldbank.org.

This research was funded by the Knowledge for Change Program.

We would like to extend our special thanks to Dr. Md. Sher Ali for his help with the data and for his expert opinion. We are thankful to Brian Blankespoor for his help with the graphics. We are also grateful to Dr. Forhad Shilpi, Dr. Johannes Zutt, and Dr. Michael Toman for their comments and suggestions on an earlier version of the paper.

The findings, interpretations, and conclusions expressed in this paper are entirely those of the authors. They do not necessarily represent the views of the International Bank for Reconstruction and Development/World Bank and its affiliated organizations, or those of the Executive Directors of the World Bank or the governments they represent. The views expressed are the authors' and do not necessarily represent the policies or views of any sponsoring agencies.

1 Recent research suggests that the sea level may rise by one meter or more in the $21^{\text {st }}$ century, which would increase the vulnerable population to about one billion by 2050 (Rahmstorf 2007, Pfeffer, Harper, and O'Neel 2008, Dasgupta et al. 2009, Vermeer and Rahmstorf 2009, Hansen and Sato 2012, Brecht et al. 2012).
}

Agricultural and Resource Economics Review 47/1 (April 2018) 66-89

(C) World Bank 2017. This is an Open Access article, distributed under the terms of the Creative Commons Attribution 3.0 IGO license (https://creativecommons.org/licenses/by/3.0/igo/), which permits unrestricted re-use, distribution, and reproduction in any medium, provided the original work is properly cited. 
Information Network 2010). Increasing salinity from saltwater intrusion will threaten their livelihoods and public health through its effects on agriculture, aquaculture, infrastructure, coastal ecosystems, and the availability of fresh water for household and commercial use. Therefore, understanding the physical and economic effects of salinity diffusion, and planning for appropriate adaptation, will be critical for long-term development and poverty alleviation in countries with vulnerable coastal regions (Brecht et al. 2012). Although sporadic measurement of soil and water salinity in coastal zones already indicates saline intrusion in many areas, data scarcity has hindered systematic empirical work on salt water intrusion and its impact on livelihoods and adaptation alternatives.

Bangladesh provides an excellent setting for investigation of these issues, because it is one of the countries most threatened by sea level rise and saltwater intrusion. In Bangladesh, about 30 percent of the cultivable land is in coastal areas where salinity is affected by tidal flooding during the wet season, direct inundation by storm surges, and movement of saline ground water during the dry season (Haque, 2006). Furthermore, new research indicates that climate change will cause significant changes in soil salinity and river salinity in coastal districts of Bangladesh during the dry season (October to May) by 2050 (Dasgupta et al. 2015a, Dasgupta et al. 2015b). In consequence, the potential impact of salinity has become a major concern for the Government of Bangladesh. Recently, the Bangladesh Climate Change Resilience Fund Management Committee highlighted salinity intrusion in coastal Bangladesh as a critical part of adaptation to climate change.

Increase in salinity is of special concern for rice production ${ }^{2}$ in Bangladesh because prior research on the sensitivity of rice grain yield ${ }^{3}$ to salinity has indicated negative effects on various components including stand establishment, panicles, tillers and spikelets per plant, leaf area index, floret sterility, individual grain size, and even the timing of heading (Hasanuzzaman et al. 2009, Grattan et al. 2002, Kahtun and Flowers 1995). Severely saltstressed seedlings have smaller and fewer tillers; less root mass; and shorter, thinner, chlorotic leaves compared to control plants not exposed to salinity (Grattan et al. 2002). Hasanuzzaman et al. (2009) reported a decrease in the leaf area index of different varieties of rice with an increase in salinity. The percentage of sterile florets in a given panicle increases with increasing salinity, resulting in reduced rice yield (Grattan, Zhen and Roberts 2002, Kahtun and Flowers 1995, Khatun, Rizzo and Flowers 1995). Salinity delays

\footnotetext{
2 Agriculture is the most important sector of the economy of Bangladesh; field crops are the main agriculture sector, and rice accounts for 71 percent of the sector (Shahid 2011).

3 The grain yield of rice has multiple determinants, such as panicle number per plant, the filled grain number per panicle, and the weight per grain (Yoshida 1983). Grain yield is significantly positively correlated with effective/productive tiller number, grain weight per plant, number of grains per panicle and grain weight per panicle (Efisue, Umunna, and Orluchukwu 2014).
} 
flowering and reduces productive tiller number, fertile florets per panicle, weight per grain, and overall rice grain yield (Khatun et al. 1995). In light of these findings, the Ministry of Agriculture in Bangladesh is especially concerned about the likely impact of progressive salinization on rice production in coastal sub-districts (upazilas).

In its National Adaptation Programme of Action (Government of the People's Republic of Bangladesh, Ministry of Environment and Forest 2005), the Government of Bangladesh has assigned high priority to projects related to adaptation of coastal agriculture to increased salinity. Resources will remain scarce, and mobilizing a cost-effective response will require an integrated spatial analysis of salinity diffusion, its socioeconomic and ecological impacts, and the costs of prevention, adaptation, and remediation. The temporal and geographic pattern of appropriate adaptive investments will depend critically on the expected economic effects of salinization in different locations. Our paper attempts to contribute by addressing the consequences of rising soil salinity in Bangladesh's coastal sub-districts for high-yielding-variety (HYV) rice production.

Rice accounts for around 71 percent of the field crop sector, and HYV Boro rice is the highest contributor to rice production of Bangladesh (Shahid 2011). In light of its importance, several studies have assessed the expected impacts of changes in temperature and rainfall on the yield of HYV Boro. For example, a time series analysis for 1972-2002 conducted by Sarker, Alam, and Gow (2012) concluded that maximum temperature had a statistically significant negative effect on the yield of Boro, minimum temperature had a statistically significant positive effect on yield, and rainfall had no effect. Basak et al. (2010) predicted a 20-percent decline in yield of two varieties of Boro by 2050 in 12 districts of Bangladesh, primarily due to increase in maximum and minimum temperatures. For their research, Basak et al. used the Decision Support System for Agrotechnology Transfer (DSATT) and the regional climate model Providing Regional Climates for Impact Studies (PRECIS).

On the other hand, Thomas et al. (2013), using the DSATT crop-modeling software, projected improved Boro yield for IPCC emission scenario A1B by 2050 with high fertilizer levels and variations in planting dates. In their analysis, Thomas et al. first modeled historic crop yield during 1950-2000, and then made projections for four global climate models (GCMs): CNRM, CSIRO, ECHAM5 and MIROC3.2. They found the greatest yield increases for ECHAM, very few areas with declining yields, some areas with yield increases of greater than 20 percent, and the majority of the country with yield increases between 10 percent and 20 percent. The results from CNRM were more pessimistic, with some areas showing yield losses between 10 percent and 20 percent. The CSIRO results were similar to those of CNRM, while the MIROC results were similar to those of ECHAM.

As a winter crop, Boro is primarily dependent on irrigation. Maniruzzaman et al. (2015) examined the availability of surface water and the net irrigation requirement of rice crops in the future under IPCC emission scenarios A1B 
and A2. They found limited change in irrigation water demand and surface water availability for Boro in their study areas of southern Bangladesh. Shahid's study on irrigation water demand for Boro rice in northwest Bangladesh also concluded that there will be no appreciable changes in total irrigation water requirements due to climate change (Shahid 2011). However, none of these studies accounted for the expected impact of salinity change on Boro yield in a changing climate, and this paper extends the research frontier in that direction.

We conduct our analysis in two steps. First, we focus on the relationship between increased soil salinity and the physical productivity of rice land. Our econometric analysis tests whether or not the yield of HYV rice has been significantly affected by variations in soil salinity across upazilas and over time. Then, with those results in hand, we investigate the impact of future salinity increases. Our findings paint a sobering picture of the impact of rising soil salinity on HYV rice production in the coastal region of Bangladesh. Many upazilas have already suffered large yield losses from rising salinity, and losses will be compounded by further salinity increases in the coming decades. Our estimates suggest that HYV rice output will decline by 15.6 percent in nine coastal upazilas where soil salinity is expected to exceed 4 deciSiemens per meter ${ }^{4}$ before 2050 .

The remainder of the paper is organized as follows. Section 2 describes the data and assesses current salinity levels and agricultural production in the coastal region; Section 3 lays the groundwork for our agricultural impact analysis by specifying and estimating an econometric model that measures the upazila-level effect of soil salinity on rice yield. In Section 4, we combine soil salinity projections with econometric estimates from Section 3 to forecast the impact of rising salinity on rice output through 2050. We discuss our findings and conclude the paper in Section 5.

\section{Data}

For this research, we assembled a large panel database that includes previously unavailable information on soil salinity and the yield of HYV rice production in 140 upazilas in four regions of southern Bangladesh: Barisal (38 upazilas), Chittagong (30), Dhaka (13), and Khulna (59). Figure 1 identifies the 140 upazilas in the study area, which spans the southern coastal regions of Bangladesh, with extensions to permit assessment of current and future salinity further inland.

Study teams collected data from local offices in each upazila on HYV rice production and prices, as well as the quantities and prices of inputs

\footnotetext{
4 The lower limit for a saline soil is conventionally set at an electrical conductivity of $4 \mathrm{dS} / \mathrm{m}$ in the soil saturation extract (Bernstein 1975).
} 


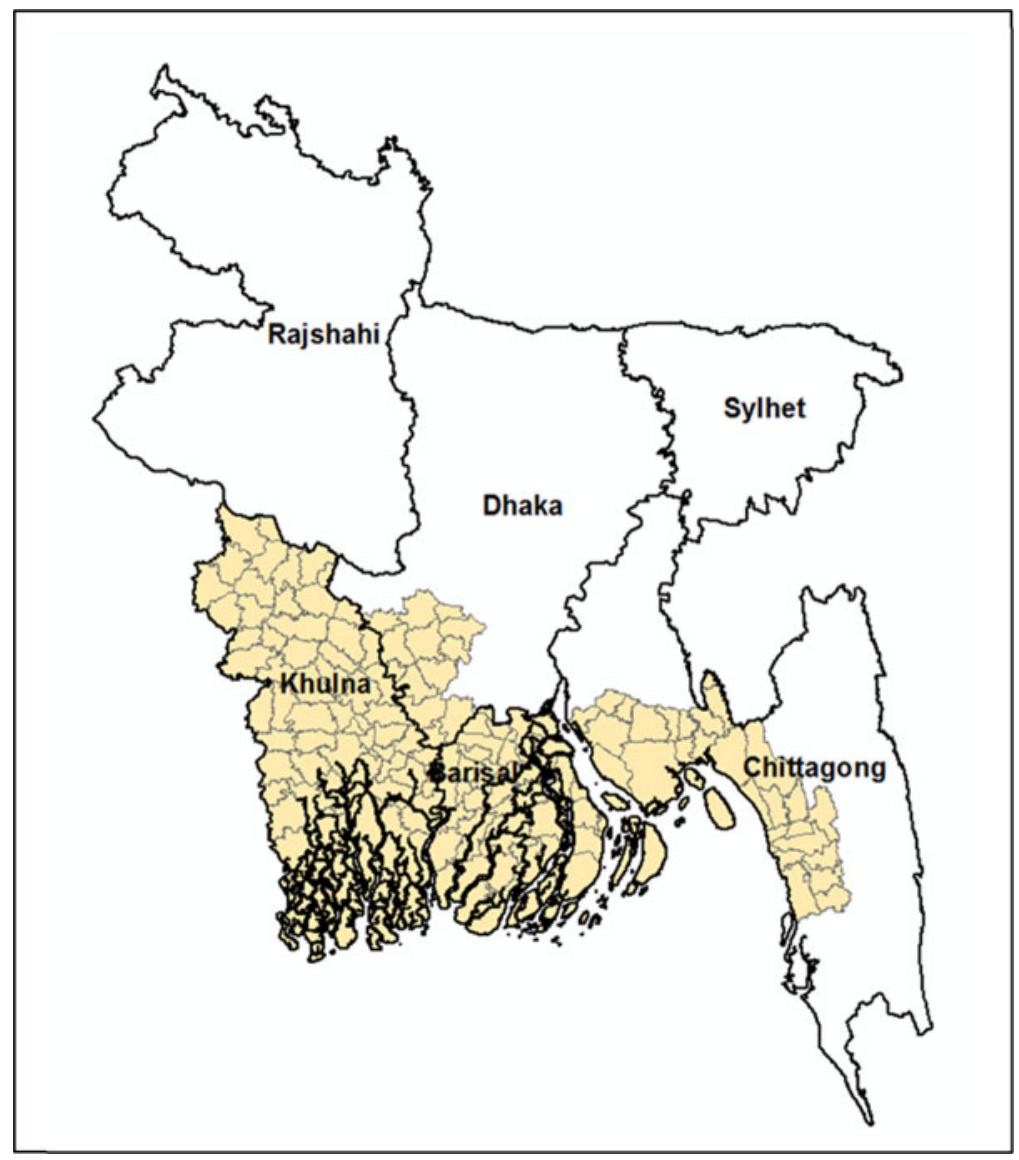

Figure 1. Study Regions and Upazilas in Bangladesh

(land, labor, seeds, fertilizer, pesticide, and power tillage) for the period 2000-2012. 5

Figure 2 shows that upazila-level mean yields for the period 2000-2012 vary from 1.2-2.8 tons/acre within the study area, with a particularly heavy concentration of low yields (1.2-1.5 tons/acre) in southern Khulna. In contrast, several upazilas in the northern tier of the study region (central Khulna, southern Dhaka, northern Barisal) have among the highest observed yields (2.3-2.8 tons/acre). Although there is a tendency for low-yield areas to concentrate near the coast and in coastal river estuaries, an evident

\footnotetext{
5 In many cases, we believe that these data have not previously been available for empirical research.
} 


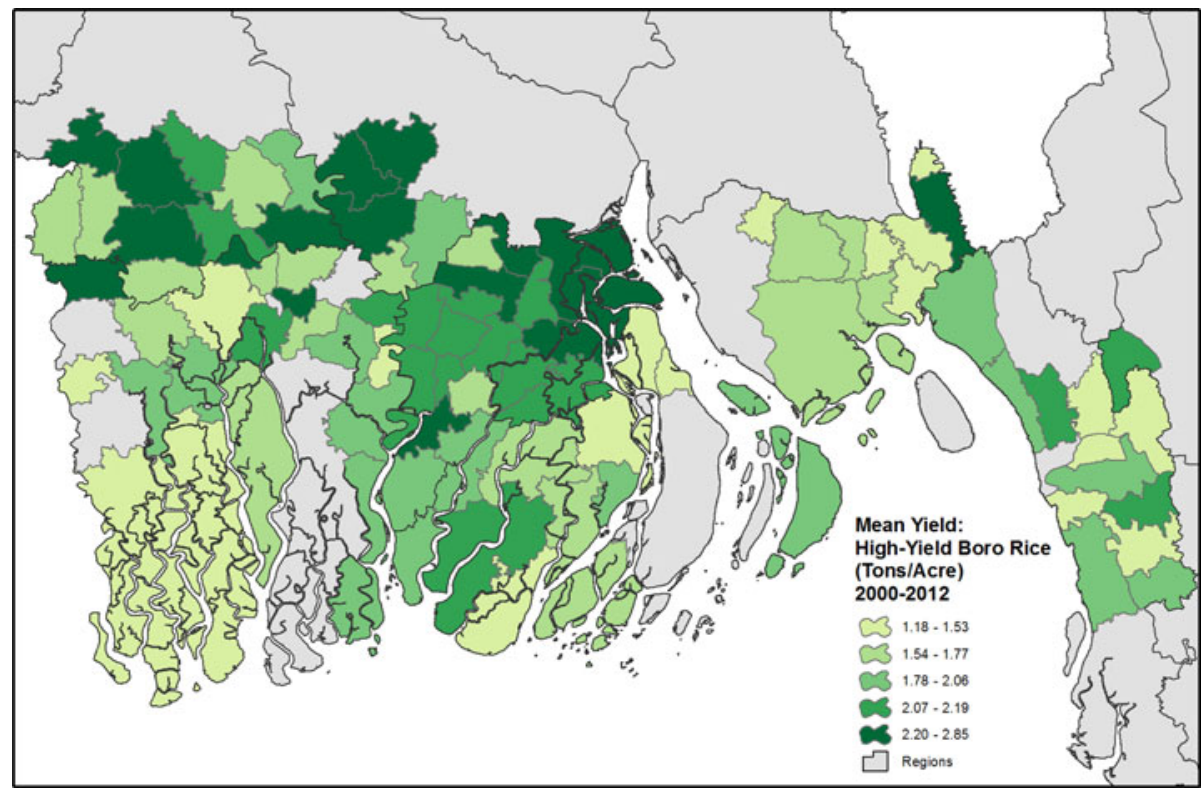

Figure 2. Mean Yield, HYV Rice (tons/acre): 2000-2012

counter-example is in southern Barisal, where the coastal area includes a cluster of upazilas with relatively high yields.

For soil salinity in coastal Bangladesh, the Soil Research Development Institute (SRDI) provided information recorded at 41 soil monitoring stations for the period 2001-2009. These data have not previously been available for empirical research. Figure 3 presents average monthly station soil salinity measures for 2001-2009, color-coded in five groups for visual comparison. Soil salinity is particularly high in the southwestern coastal region and in Khulna and Satkhira districts. ${ }^{6}$

\footnotetext{
6 Location-specific soil salinity as measured by land-based monitors is generally related to salinity in nearby rivers via annual flooding and tidal flooding. River salinity, in turn, is affected by upstream fresh water flow, precipitation, rate of evapotranspiration and ground water table infusion. In the southwestern coastal region there is a shortage of freshwater from the upstream river system in the dry season. The water from the Ganges River, which flows through its distributary Gorai River, is the major source of fresh water for the region; the offtake of the Gorai is almost dry during December to May. The salinity level at the Bay of Bengal during December to May is also comparatively high; and saline water intrudes via tidal effects through the major rivers: the Baleswar, lower Meghna, Malancha, Pussur, Sibsa, and Tnetulia. The topography of the region is very flat; strong tidal effects sometimes travel $200 \mathrm{~km}$ upstream from the coast. In addition, the increase of temperature in the dry season causes capillary rise of saline water. Evaporation leaves salt on the soil surface, thereby increasing soil salinity.
} 


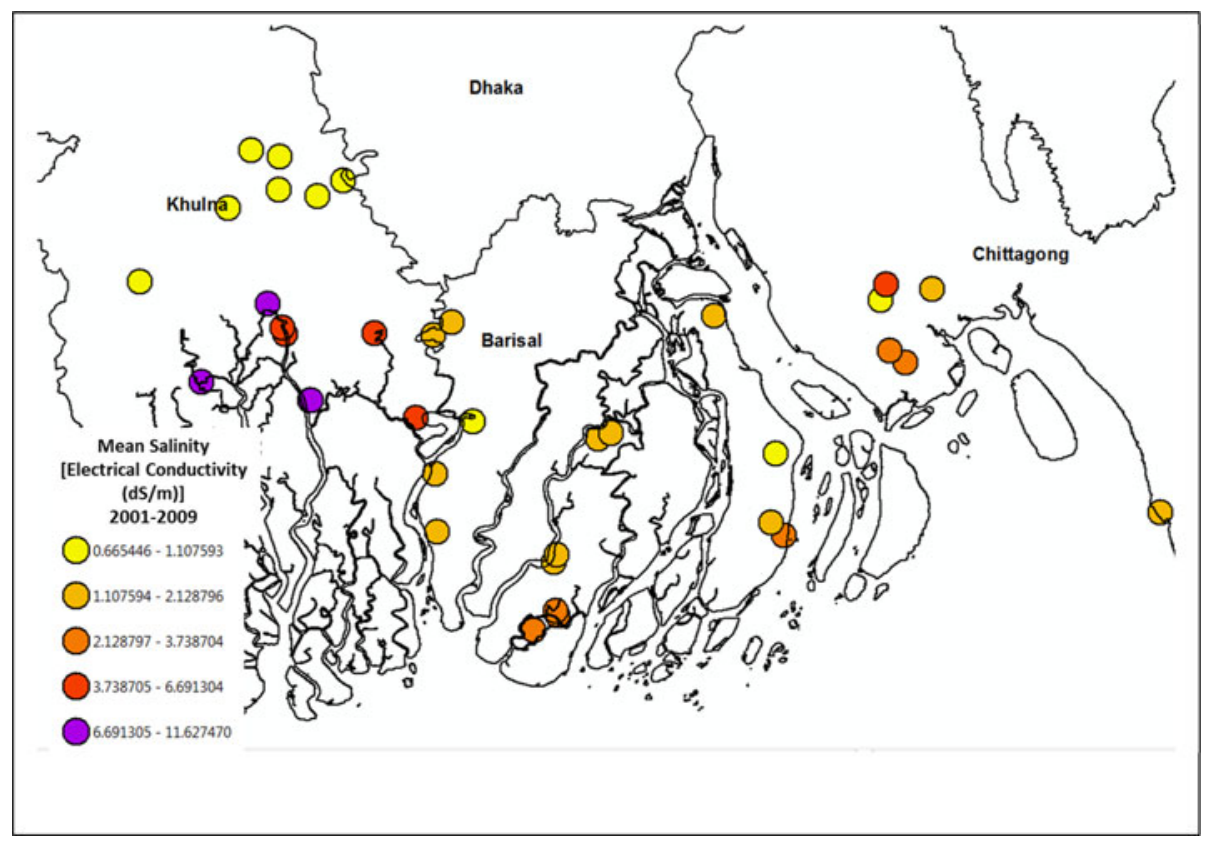

Figure 3. Mean Salinity Measures for Land Stations (dS/m): 2001-2009

For upazila-level soil salinity, we calculate the weighted mean of measures from monitoring stations within $30 \mathrm{~km}$ of the upazila centroid, using weights that are inversely proportional to squared distances.

Our database also includes measures of temperature and rainfall recorded by the Bangladesh Meteorological Department (BMD)'s monitoring stations. For upazila-level temperature and rainfall, we calculate the measures for upazila centroids using data from proximate stations. We calculate weighted mean temperature and rainfall at the upazila centroid using the same distanceweighting approach for GDM weather stations within $50 \mathrm{~km}$. All upazila centroids fall within $50 \mathrm{~km}$ of at least one BMD weather station, so our coverage is complete for rainfall and temperature.

For soil salinity, a binding constraint is imposed by the need for observations from monitors within $30 \mathrm{~km}$ of upazila centroids, limiting our soil salinity measures to 69 upazilas. Although our data provide a new view of local agricultural production, records obtained from many upazilas have significant gaps in coverage. For the upazila-supplied variables, observations increase by year, from 76 in 2001 to 94 in 2012. The dominant constraint is imposed by land rent, which has far fewer observations than the other variables. Overall, a critical constraint for multivariate estimation is imposed by the requirement of availability for all variables. Complete data are available for 
only 14 upazilas for eleven years, and 13 in 2011. This limitation has strongly affected the estimation strategy described in the following section.

\section{Relationship between Soil Salinity and HYV Rice Yield}

Salinity adversely affects the growth and yield of a rice plant in two main ways: (i) The plant must spend more energy to draw water from the soil into its roots due to osmotic effects of salt, and the process diverts some of the energy that a plant otherwise would use to survive and grow (Bernstein 1995); and (ii) the ion-excess effect of salinity may lead to leaf necrosis, premature leaf drop, lower growth, and reduced yield (Greenway and Munns 1980).

To test the relationship between soil salinity and HYV rice yield, we maximize degrees of freedom by estimating a reduced-form model that links yield per acre to soil salinity, temperature, and rainfall: ${ }^{7,8}$

$$
\begin{aligned}
& \ln Y_{i t}=\beta_{0}+\beta_{1} \ln T_{i t}+\beta_{2} \ln R_{i t}+\beta_{3} \ln S_{i t}+\varepsilon_{i t} \\
& \text { Expectations: } \beta_{1}, \beta_{2}<0
\end{aligned}
$$

where, for upazila i in year t:

$$
\begin{aligned}
& \mathrm{Y}_{\mathrm{it}}=\mathrm{HYV} \text { paddy production per acre } \\
& \mathrm{T}_{\mathrm{it}}=\text { Mean maximum temperature } \\
& \mathrm{R}_{\mathrm{it}}=\text { Mean rainfall } \\
& \mathrm{S}_{\mathrm{it}}=\text { Mean soil salinity during the four most saline months, measured by } \\
& \quad \text { sample electrical conductivity }(\mathrm{dS} / \mathrm{m})^{9} \\
& \varepsilon_{\mathrm{it}}=\text { Random error term with upazila and yearly components }
\end{aligned}
$$

\footnotetext{
7 Our specification includes only contemporaneous measures of soil salinity. As a reviewer has noted, inclusion of lagged soil salinity values could be warranted if salinity were subject to irreversible threshold effects. However, salinity exhibits substantial inter-annual variability in all of our sample upazilas. Dasgupta et al. (2015b) identify the principal source of this variability: diffusion from nearby rivers, whose salinity is driven by the interaction of fluctuating freshwater flow volumes, tides and storm surges.

8 Our econometric exercise incorporates particular specifications for temperature, rainfall and salinity that reflect local conditions relevant for yield analysis. In southern Bangladesh, the HYV Boro season is from late December/early January to May. However, Boro harvesting is generally complete by mid-April. Previously cited studies (e.g., Sarker, Alam and Gow 2012, Basak et al. 2010) have emphasized the maximum and minimum temperature during the growing season as important determinants of Boro yield. Boro production is based on irrigation supplemented by rainfall. Therefore, we have incorporated mean temperature and mean rainfall during the growing season of HYV Boro in our analysis.

${ }_{9}$ We have also tested for the impact of mean salinity during the four middle months. These results are significant, but the effect is stronger for the four highest months.
} 
We estimate the effect of soil salinity using both continuous and threshold specifications. ${ }^{10}$ Table 1 presents our estimates for five cases: OLS, two panel estimators (RE, FE), and two spatial panel estimators (Sp,RE; Sp,FE). Panel estimation employs the standard xtreg estimator in Stata. Spatial econometric estimation employs the xsmle estimator in Stata, developed by Belotti, Hughes, and Mortari $(2014,2016)$, who draw on Cameron, Gelbach and Miller (2011), Elhorst (2010), Lee and Yu (2010), and earlier work by Anselin (2001, 2002), Barrios et al. (2010), Kapoor, Kelejian and Prucha (2007), Kelejian and Prucha (1998), Kelejian, Prucha, and Yuzefovich (2004), and Kelejian and Prucha (2006).

Prior experimentation has suggested that $4.0 \mathrm{dS} / \mathrm{m}$ is an appropriate bound for estimating salinity threshold effects. Table 2 presents comparative parameter estimates and significance levels for soil salinity using thresholds in the range $[1 \mathrm{dS} / \mathrm{m}-6 \mathrm{dS} / \mathrm{m}]$. Classical significance is first achieved at $4 \mathrm{dS} / \mathrm{m}$, so we have chosen that threshold for the final regressions. ${ }^{11}$

In both continuous and threshold cases, we find highly significant spatial autocorrelation for the 39 upazilas in the sample. The relevant spatial autocorrelation parameters and t-statistics are reported in Table 1. Our estimation exercise incorporates an inverse-distance spatial weights matrix; reported standard errors are robust to spatial autocorrelation (Belotti, et al. 2016). Inspection of the continuous and threshold results for the spatial estimators shows that the threshold specification is clearly stronger. It produces results for salinity that are highly significant in all cases, while salinity achieves significance in only one of five continuous cases (OLS). ${ }^{12}$ As

10 With plentiful data, a full exercise could incorporate capital and labor into the yield model using instrumental variables estimation. An equivalent test of salinity's impact would augment the reduced form with the available instruments themselves - price measures for labor and other inputs. In this case, incorporation of the appropriate instruments would radically reduce degrees of freedom because exclusion of missing values would yield a small data set. Our sparse reduced form strategy maximizes degrees of freedom and minimizes standard errors, but we recognize the possibility of estimation bias if excluded instruments are significantly correlated with salinity. We have used the available data to calculate separate correlation coefficients for salinity and each exogenous price measure: All correlations are negative and lie between -0.25 and -0.05 . Although these correlations are modest, we cannot exclude the possibility of some bias in our estimate of salinity's impact.

11 Our econometric result also coincides with the salinity threshold established by technical experimentation (Suryanarayanan, 2010). Bernstein (1975) notes that an electrical conductivity of $4 \mathrm{dS} / \mathrm{m}$ in the soil saturation extract is the lower limit for a saline soil and therefore a critical threshold.

12 Our estimation approach incorporates spatial fixed effects, but the possibility remains that part of the effect estimated for salinity may be due to other time-varying determinants of yield. As we noted previously, relatively sparse measures for relevant price variables have restricted our econometric exercise to the reduced form in (1). As one check, however, we have re-run the regressions in Table 1 with the addition of the most plentifully-represented price variable, the annual market price for HYV paddy at the upazila level. The magnitudes and significance of our parameter estimates for salinity are not affected by this addition. The results are available from the authors on request. 
Table 1. Soil Salinity and Yield per Acre in HYV Rice Production All variables in logs except threshold salinity dummy variables in (6-10) Dependent variable: Rice yield (metric tons/acre)

\begin{tabular}{|c|c|c|c|c|c|c|c|c|c|c|}
\hline & \multicolumn{10}{|c|}{ Salinity Measure } \\
\hline & \multicolumn{5}{|c|}{ Continuous } & \multicolumn{5}{|c|}{$\begin{array}{l}\text { Threshold } \\
\text { ( }>4 \mathrm{dS} / \mathrm{m})\end{array}$} \\
\hline & (1) & (2) & (3) & (4) & (5) & (6) & (7) & (8) & (9) & (10) \\
\hline & OLS & RE & FE & Sp,RE & Sp,FE & OLS & $\mathbf{R E}$ & FE & Sp,RE & Sp,FE \\
\hline $\begin{array}{l}\text { Mean Max Temp, } \\
\text { Highest } 4 \text { Months }\end{array}$ & $\begin{array}{c}1.997 \\
(3.98)^{* *}\end{array}$ & $\begin{array}{c}1.265 \\
(2.89)^{* *}\end{array}$ & $\begin{array}{c}1.082 \\
(2.35)^{*}\end{array}$ & $\begin{array}{l}1.436 \\
(1.72)\end{array}$ & $\begin{array}{l}1.638 \\
(1.47)\end{array}$ & $\begin{array}{l}2.165 \\
(4.34)\end{array}$ & $\begin{array}{c}1.131 \\
(2.64)^{* *}\end{array}$ & $\begin{array}{l}0.939 \\
(2.10)^{*}\end{array}$ & $\begin{array}{l}0.942 \\
(1.24)\end{array}$ & $\begin{array}{l}0.979 \\
(1.00)\end{array}$ \\
\hline $\begin{array}{l}\text { Mean Rainfall, } \\
\text { Highest } 4 \text { Months }\end{array}$ & $\begin{array}{l}-0.123 \\
(2.41)^{*}\end{array}$ & $\begin{array}{l}-0.079 \\
(2.28)^{*}\end{array}$ & $\begin{array}{l}-0.073 \\
(2.09)^{*}\end{array}$ & $\begin{array}{l}-0.084 \\
(1.01)^{*}\end{array}$ & $\begin{array}{c}-0.099 \\
(0.98)\end{array}$ & $\begin{array}{l}-0.122 \\
(2.39)^{*}\end{array}$ & $\begin{array}{l}-0.078 \\
(2.28)^{*}\end{array}$ & $\begin{array}{l}-0.073 \\
(2.09)^{*}\end{array}$ & $\begin{array}{c}-0.076 \\
(0.99)\end{array}$ & $\begin{array}{c}-0.087 \\
(0.93)\end{array}$ \\
\hline $\begin{array}{l}\text { Mean Soil Salinity } \\
\text { Highest } 4 \text { Months }\end{array}$ & $\begin{array}{l}-0.037 \\
(3.37)^{* *}\end{array}$ & $\begin{array}{c}-0.023 \\
(1.46)\end{array}$ & $\begin{array}{c}-0.017 \\
(0.93)\end{array}$ & $\begin{array}{c}-0.090 \\
(1.90)\end{array}$ & $\begin{array}{l}-0.096 \\
(1.52)\end{array}$ & $\begin{array}{l}-0.084 \\
(4.02)^{* *}\end{array}$ & $\begin{array}{l}-0.078 \\
(2.96)^{* *}\end{array}$ & $\begin{array}{l}-0.079 \\
(2.77)^{* *}\end{array}$ & $\begin{array}{l}-0.169 \\
(2.45)^{* *}\end{array}$ & $\begin{array}{l}-0.169 \\
(1.99)^{*}\end{array}$ \\
\hline Constant & $\begin{array}{l}-5.654 \\
(3.18)^{* *}\end{array}$ & $\begin{array}{c}-3.359 \\
(1.81)\end{array}$ & $\begin{array}{l}-2.757 \\
(1.36)\end{array}$ & & & $\begin{array}{l}-6.266 \\
(2.84)^{* *}\end{array}$ & $\begin{array}{l}-2.887 \\
(2.07)^{*}\end{array}$ & $\begin{array}{l}-2.247 \\
(1.63)\end{array}$ & & \\
\hline $\begin{array}{l}\text { Spatial } \\
\text { autocorrelation }\end{array}$ & & & & $\begin{array}{c}.823 \\
(7.83)^{* *}\end{array}$ & $\begin{array}{c}.955 \\
(10.12) \\
* *\end{array}$ & & & & $\begin{array}{c}.785 \\
(7.41)^{* *}\end{array}$ & $\begin{array}{c}.920 \\
(9.37)^{*}\end{array}$ \\
\hline Observations & 468 & 468 & 468 & 468 & 468 & 468 & 468 & 468 & 468 & 468 \\
\hline R-squared & 0.14 & 0.14 & 0.14 & 0.14 & 0.06 & 0.15 & 0.14 & 0.13 & 0.11 & 0.06 \\
\hline Upzilas & 39 & 39 & 39 & 39 & 39 & 39 & 39 & 39 & 39 & 39 \\
\hline
\end{tabular}

Absolute value of $t$ statistics in parentheses

*significant at 5\%; ${ }^{* *}$ significant at $1 \%$ 
Table 2. Spatial Regression Parameter Estimates (Fixed Effects): HYV Yield Impact, Mean Soil Salinity, Highest 4 Months $(\mathrm{N}=468)$

\begin{tabular}{lccc}
\hline Salinity $(\mathbf{d S} / \mathbf{m})>$ & Parameter & Std. Error & t-Statistic \\
\hline 1 & -0.117 & 0.078 & -1.510 \\
2 & -0.051 & 0.072 & -0.710 \\
3 & -0.068 & 0.073 & -0.940 \\
4 & -0.169 & 0.085 & $-1.990^{*}$ \\
5 & -0.187 & 0.093 & $-2.000^{*}$ \\
6 & -0.221 & 0.109 & $-2.020^{*}$ \\
\hline
\end{tabular}

* significant at $5 \%$

we note in footnote 12, our results dovetail with field research that finds significant salinity effects only above a threshold value of $4.0 \mathrm{dS} / \mathrm{m}$. In contrast, the continuous model posits a linear relationship between yield and below-threshold salinity that is not consistent with technical research.

Results for the two threshold spatial estimators are nearly identical; we choose fixed effects as the preferred estimator. Table 3 provides information on relative yield sensitivity to salinity, rainfall, and temperature. For each determinant, we use the spatial autocorrelation (FE) results to estimate yields for sample minimum and maximum values, holding the other two determinants constant at their mean levels. Increases from minimum to maximum values produce yield changes of -60.0 percent for soil salinity, -46.3 percent for rainfall, and 80.3 percent for temperature. We conclude

Table 3. HYV Yield Impacts: Temperature, Rainfall, Salinity (Regression-Estimated Impacts at Mean Values for Other Variables)

\begin{tabular}{lccccc}
\hline & $\begin{array}{l}\text { Mean Max } \\
\text { Temp, } \\
\text { Highest 4 } \\
\text { Months (C) }\end{array}$ & $\begin{array}{l}\text { Mean } \\
\text { Rainfall, } \\
\text { Highest 4 } \\
\text { Months (cm) }\end{array}$ & $\begin{array}{l}\text { Mean Soil } \\
\text { Salinity, } \\
\text { Highest 4 } \\
\text { Months (dS/m) }\end{array}$ & $\begin{array}{l}\text { Tons } \\
\text { HYV } \\
\text { Paddy } \\
\text { per Acre }\end{array}$ & $\begin{array}{l}\text { \% } \\
\text { Change }\end{array}$ \\
Effect & 33.70 & 375.81 & 0.00 & 2.88 & \\
\hline $\begin{array}{c}\text { Salinity (@Mean } \\
\text { Temperature, }\end{array}$ & 33.70 & 375.81 & 1.00 & 1.15 & -60.00 \\
$\quad$ Rainfall) & & & & & \\
$\begin{array}{l}\text { Rainfall (@Mean } \\
\text { Salinity, }\end{array}$ & 33.70 & 206.82 & 0.35 & 2.97 & \\
$\quad$ Temperature) & 33.70 & 720.66 & 0.35 & 1.60 & -46.27 \\
$\begin{array}{c}\text { Temperature } \\
\text { (@Mean Salinity, }\end{array}$ & 31.37 & 375.81 & & & \\
Rainfall) & 36.23 & 375.81 & 0.35 & 1.19 & \\
\hline
\end{tabular}


that the impact of soil salinity on yields in our sample of upazilas is comparable in magnitude to the impacts of rainfall and temperature.

Our results for temperature and rainfall illustrate the effect of adjusting for spatial autocorrelation in this context. In the continuous and threshold cases, both weather variables are statistically significant in most of the OLS and panel estimates. In the FE panel estimate (8) for threshold salinity, for example, each 1 percent increase in temperature is associated with a 0.94 percent increase in rice yield; each 1 percent increase in rainfall lowers yield by 0.07 percent. After adjustment for spatial autocorrelation in (9) and (10), the estimated impacts of temperature and rainfall remain virtually identical to the panel estimates (7 and 8). The estimated standard errors are larger, however, so both variables lose classical significance. ${ }^{13}$

In summary, our investigation of the relationships linking soil salinity to the yield of HYV rice production indicates that the best-fit relationship between yield and soil salinity is a threshold model in which upazilas whose soil salinity exceeds $4 \mathrm{dS} / \mathrm{m}$ have substantially lower yield than their counterparts. With constant acreage and constant price ${ }^{14}$, lower yield implies that income from rice production declines with salinity. The magnitude of the impact can be expected to vary by upazila, according to local conditions.

\section{Future Salinity and HYV Rice Productivity}

The southwest coastal region of Bangladesh already has a serious soil salinity problem from tidal effects, storm surges, and the spread and increasing intensity of river water salinity. The problem is expected to worsen as climate change proceeds (SRDI 2000, SRDI 2010, Dasgupta et al. 2014).

Past assessments of salinization have employed a variety of methods. Sarwar (2005) and SRDI (1998a, 1998b, 2000, 2010) documented changes in salinity that have accompanied coastal subsidence and thermal expansion of the ocean. These studies typically simulated salinity change in rivers and estuaries using hydraulic engineering models and compared the results with actual measures (Bhuiyan and Dutta 2011, Aerts et al. 2000, Nobi and Das Gupta 1997). In the most comprehensive study to date, Dasgupta et al. (2015a) extended recent salinity trends in coastal rivers to 2050 with a projection model that links the spread and intensity of salinity to changes in sea level, temperature, rainfall, and altered riverine flows from the Himalayas for twenty-seven alternative scenarios of climate change. The study provides new estimates of location-specific river salinity through 2050.

13 Temperature and rainfall have a relatively high correlation in the sample $(\rho=0.69)$, so collinearity could explain the loss of significance for temperature and rainfall. However, collinearity does not appear to explain this. In two additional regression runs, which exclude rainfall and temperature separately, we find the same loss of significance.

14 The underlying assumption is that small rice farmers are price takers. 
In another recent study, Dasgupta et al. (2015b) developed location-specific soil salinity projections for 69 upazilas of coastal Bangladesh through 2050 from climate-induced changes in river salinity and projections of rainfall and temperature based on time trends for 20 Bangladesh Meteorological Department weather stations in the coastal region. The projections are based on a spatial econometric model linking soil salinity to proximate river salinity, land elevation, rainfall, and temperature. The findings indicate that climate change poses a major soil salinization risk for coastal Bangladesh.

In this section, we explore the potential consequences of increased soil salinity for rice yields using soil salinity projections from Dasgupta et al. (2015b). Our sample comprises 69 upazilas with the requisite data in Khulna (29), Barisal (27), Chittagong (9), and Dhaka (4).

To project rice yields, we use the fixed-effects parameter estimates from (10) in Table 1. We incorporate long-term projections of rainfall and temperature that we have produced using data from 20 coastal region BMD weather stations for the period 1990-2012. ${ }^{15}$ The temperature analysis estimates a time trend in a panel regression that includes both station fixed effects and station-specific monthly variations. The rainfall analysis uses the same approach but performs the estimation for log rainfall to ensure positive projections in drier months. Robust regression is employed to ensure against any additional outlier effects. The full results are not reported here, because the regressions include 11 monthly dummies, 19 weather station dummies, and 209 interactions of the monthly and weather station dummies, as well as the time trend. ${ }^{16}$ Table 4 presents the estimates of primary interest: monthly time trends for temperature and rainfall.

We use the soil salinity estimates from Dasgupta et al. (2015b) (see Appendix Table $\mathrm{A}^{17}$ ) to project mean soil salinity in the four most saline months from 2012 to 2050. For the 56 upazilas with observations for rice output and acreage in 2012, we calculate initial yield for our projection directly. The remaining 13 upazilas have no yield observations for $2000-2012$, so we use mean 2012 yield in their respective regions.

Our exercise sets baseline yield as equal to the yield in 2012 for the entire projection period. For comparison, we identify upazilas with salinity measures lower than $4 \mathrm{dS} / \mathrm{m}$ in 2012 and higher than this threshold in 2050. We apply our econometric result ${ }^{18}$ to these upazilas, reducing baseline yield by 15.55 percent in each year after the $4 \mathrm{dS} / \mathrm{m}$ threshold is exceeded.

\footnotetext{
15 Monthly mean rainfall and maximum temperature in 1990 and 2001 for all 20 stations, as well as projections for 2050, are available from the authors upon request.

16 Full results are available from the authors on request.

17 Table A1 presents soil salinity measures in 2012 and 2050, sorted in descending order of salinity in 2050. We also include information on changes to highlight the steady increases in salinity for all upazilas that remain below $4 \mathrm{dS} / \mathrm{m}$ in 2050.

18 We translate the log result in Table $1(10),-0.169$, to percent change form: $-15.55 \%$
} 
Table 4. Robust Panel Regression Estimates: Temperature and rainfall at 20 BMD weather stations, 1990-2010

\begin{tabular}{lcrcccc}
\hline & & & & $\begin{array}{l}\text { BMD } \\
\text { Weather } \\
\text { Stations }\end{array}$ & $\begin{array}{l}\text { Monthly } \\
\text { Observations }\end{array}$ \\
\hline Temperature & 0.0034 & $21.93^{* *}$ & $\mathrm{~F}(240,4799)=197.15$ & 20 & 5,040 \\
Log Rainfall & -0.00058 & $4.50^{* *}$ & $\mathrm{~F}(240,4775)=379.89$ & 20 & 5,016 \\
\hline
\end{tabular}

Table 5 provides information on the threshold status of our sample upazilas. By 2012, 18 have already exceeded the threshold (17 in Khulna and 1 in Barisal). Because the yield-reducing effects have already occurred for these upazilas, their baseline and comparative yields are both set at their 2012 yields for the projection. During the period 2013-2050, soil salinity goes past the threshold value of $4 \mathrm{dS} / \mathrm{m}$ in 9 upazilas (Barisal (6), Chittagong (2), Dhaka (1)). For these areas, we reduce baseline yield by 15.55 percent for each year after the threshold is exceeded.

The remaining 42 upazilas remain below the threshold in 2050, so their baseline and comparative yields are set at their 2012 levels. As expected, our output results are skew-distributed, with large declines confined to upazilas that pass the $4 \mathrm{dS} / \mathrm{m}$ threshold during the projection period.

We consolidate the upazila projections into projections at the regional level. In Barisal, where 6 upazilas reach the threshold of $4 \mathrm{dS} / \mathrm{m}$ during the projection period, the impact on yields is sufficient to reduce output by 7.7 percent. In Chittagong, which has fewer upazilas in the sample, rising soil salinity in two upazilas exceeds the $4 \mathrm{dS} / \mathrm{m}$ threshold before 2050 . The result is a 5.6 percent reduction in output for the region. Dhaka has only one upazila that crosses the threshold during the projection period, so its output declines by 1.1 percent. Finally, Khulna begins the projection period with several upazilas already beyond the salinity threshold. No upazila crosses the threshold during the projection period, so Kulna's output decline is 0 percent.

Potential future changes in soil salinity are also highlighted in Table 6, which tabulates upazilas by soil salinity group in 2012 and 2050 .

There are 21 upazilas with measures between 1.0 and $2.0 \mathrm{dS} / \mathrm{m}$ in 2012, but only 1 upazila remains in this group by 2050. The number of upazilas in the next group $(2.0-3.0 \mathrm{dS} / \mathrm{m})$ remains nearly constant during the projection period, but the population of the near-threshold group (3.0-4.0 dS/m) doubles, from 12 to 24 . Although the period after 2050 is beyond our projection interval, these results strongly suggest that 24 more upazilas will cross the threshold within a few decades after 2050 and therefore experience significant decline in the output of HYV rice. 
Table 5. Upazila Salinity Threshold Status by Period

\begin{tabular}{lccc}
\hline Region & 2012 or Earlier & 2013-2050 & After 2050 \\
\hline Barisal & 1 & 6 & 20 \\
Chittagong & 0 & 2 & 7 \\
Dhaka & 0 & 1 & 3 \\
Khulna & 17 & 0 & 12 \\
\hline
\end{tabular}

\section{Discussion and Conclusions}

Agriculture is an important economic sector in Bangladesh, contributing 13.1 percent of gross domestic product and employing 47.5 percent of the labor force (BBS 2010). In 2012-2013, Bangladesh produced 33.8 million tons of rice, including 18.8 million tons of winter rice. Therefore, the potential impact of salinity on HYV winter rice has become a major concern for the government of Bangladesh and its affiliated research institutions.

Prior research on this issue using local surveys and descriptive statistics suggests significant agricultural productivity losses from rising soil salinity (Karim, Hussain and Ahmed 1990, World Bank 2000, Rahman and Ahsan 2001, Petersen and Shireen 2001, Hassan and Shah 2006, Haque 2006, UK DEFR 2007, Mahmood et al. 2010, Thomas et al. 2013). ${ }^{19}$ Thomas et al. (2013) provided a detailed technical assessment of potential climate impacts on agriculture in Bangladesh, using projections from several global climate models and technical parameters incorporated in available crop-modeling software. While the authors provide results from a survey of farmers on sources of crop losses, ${ }^{20}$ including soil salinity, they do not attempt to mobilize the requisite data for direct estimation of salinity impacts.

In this paper, we have developed, estimated, and applied a system for projecting the impact of rising soil salinity on outputs of HYV rice in the upazilas of coastal Bangladesh. We estimate the impact of soil salinity on agriculture using spatial econometric methods. Our estimation exercise indicates that HYV rice yield is significantly (15.6 percent) lower in upazilas where soil salinity is greater than $4 \mathrm{dS} / \mathrm{m}$.

In the projection section of the paper, we use our econometric yield model to forecast the future impact of soil salinity on rice outputs. We project output declines of 15.6 percent in 9 upazilas that cross the $4 \mathrm{dS} / \mathrm{m}$ salinity threshold before 2050. Our results also suggest that losses beyond 2050 are likely to

\footnotetext{
19 During the past several years, researchers have also begun to address the global economics of sectoral adaptation to higher temperatures, greater variation in rainfall, water scarcity and inundation of coastal areas (Cline 2007; Margulis et al. 2010; Dasgupta et al. 2009).

20 Thomas et al. (2013), Table 3. 17, p. 45.
} 
Table 6. Upazilas by Soil Salinity Class, 2012 and 2015

\begin{tabular}{lcr}
\hline & \multicolumn{2}{c}{ Upazila Counts } \\
\cline { 2 - 3 } Soil Salinity (dS/m) & $\mathbf{2 0 1 2}$ & $\mathbf{2 0 5 0}$ \\
\hline $1.01-2.00$ & 21 & 1 \\
$2.01-3.00$ & 18 & 17 \\
$3.01-4.00$ & 12 & 24 \\
$4.01+$ & 18 & 27 \\
Total & 69 & 69 \\
\hline
\end{tabular}

exceed the projected losses before 2050, because the number of upazilas crossing the $4 \mathrm{dS} / \mathrm{m}$ threshold after 2050 (24) greatly exceeds the number projected to cross the threshold between 2012 and 2050 (9).

Our results paint a sobering picture of the impact of rising soil salinity on HYV rice production in the coastal region of Bangladesh. The problem is most severe in the southwest coastal region ${ }^{21}$, as the region already has a serious problem from the spread and increasing intensity of salinization of river water and soil, and it is feared that the problem of salinity will worsen due to the changing climate. $^{22}$ Many upazilas in the southwest coastal region have already suffered large yield losses from rising salinity, and coastal region losses will be compounded by further salinity increases in the coming decades. This inexorable process will continue as long as the sea continues to rise and salinity increases in coastal rivers. We see no prospect for near-term relief, because rising global greenhouse gas emissions continue to propel rapid climate change and melting of the polar ice caps.

In densely populated and land-scarce Bangladesh, poor households are disadvantaged with respect to land access. Many end up settling in low-lying coastal areas that are vulnerable to salinity incursion and inundation from sea level rise and storm surges. A poverty-mapping exercise by the Bureau of Statistics in Bangladesh, the World Bank, and the World Food Programme (World Bank, World Food Programme, and Bangladesh Bureau of Statistics 2010) estimates that around 11.8 million poor people were located in 19 coastal districts in 2010. Alarmingly, this figure includes many extremely

\footnotetext{
21 The southwest coastal zone is bounded by the Baleswar River in the east and the Raimongal River, and the border with India in the west.

22 In contrast, salinity is low in the south central and southeastern coastal zones in Bangladesh. The low salinity level in the south-central zone throughout the year results from the considerable volume of freshwater discharge from the Padma River and the Lower Meghna River, which is diverted into the region through the Arialkhan, Buriswar, and Bishkhali Rivers. The Feni, Little Feni, and Bamni Rivers flow in the southeast and are controlled by regulators at the outfalls to prevent landward movement of saline water during high tides.
} 
poor households that are not even able to afford adequate nutrition. This problem will almost certainly be aggravated by declining rice productivity as soil salinization increases. Other health- and infrastructure-related impacts are also likely, and future research should focus on their implications for poor households.

The government of Bangladesh is aware of the expected adverse effects of climate change on HYV rice production in the coastal region, and it has invested in promoting suitable adaptation measures. The Bangladesh Rice Research Institute is conducting research on salt-resistant varieties of rice. One salt-resistant strain, BRRI Dhan 47, was released by the country's National Seed Board in 2007, and it can be found in a growing number of coastal community markets at the same price as conventional rice. ${ }^{23}$ Another salt resistant variety, BINA Dhan 10, was introduced by the Bangladesh Institute of Nuclear Agriculture in 2012. Government agricultural extension officials are providing training in cultivation of salt-resistant varieties. However, the future of these initiatives will depend on their relative profitability as well as on the adaptability of farmers and acceptance by consumers (for example, see Greiner and Gregg 2011). Compilation of location-specific adaptation alternatives and the cost of adaptation options are subjects of our ongoing research.

We believe the analysis in this paper also will be of interest to other developing countries with low-lying coastal areas. Given the general lack of studies on diffusion and impacts of salinity in the developing world, we hope that our analysis will raise awareness and prompt countries (at least those for which inundation from SLR has been identified as a major problem associated with climate change) to initiate detailed, location-specific assessments of potential impacts of salinity in coastal areas, including analyses of the impacts on agriculture and other socioeconomic impacts of salinity changes. ${ }^{24}$ Such estimates may then trigger actions aimed at facilitating increased resilience of coastal agriculture and developing alternative livelihood options for coastal communities exposed to imminent salinity risks.

\section{References}

Aerts, L.J., A. Hassan, H.H.G. Savenije, and M.F. Khan. 2000. "Using GIS Tools and Rapid Assessment Techniques for Determining Salt Intrusion: STREAM - a river basin

23 BRRI Dhan 47 can withstand 12-14 dS/m salinity of land while they are tender, and $6 \mathrm{dS} / \mathrm{m}$ in their entire lifespan of 152-155 days., whereas salt tolerance capacities of other conventional high-yielding rice varieties are below $4 \mathrm{dS} / \mathrm{m}$. http://www.irinnews.org/report/88426/ bangladesh-salt-resistant-rice-offers-hope-to-farmers

${ }_{24}$ Several countries in South and East Asia, including India, Pakistan, Sri Lanka, China, Philippines and Vietnam have expressed strong interest in undertaking similar research. 
management instrument." Physics and Chemistry of the Earth, Part B Hydrology, Oceans and Atmosphere 25(3): 265-273. https://doi.org/10.1016/S1464-1909(00)00014-9

Anselin, L. 2001. "Spatial Effects in Econometric Practice in Environmental and Resource Economics." American Journal of Agricultural Economics 83(3): 705-710.

- 2002. "Under the Hood: Issues in the Specification and Interpretation of Spatial Regression Models." Agricultural Economics 27(3): 247-267. https://doi.org/10.1111/j. 1574-0862.2002.tb00120

Barrios, T., R. Diamond, G.W. Imbens, and M. Kolesár. 2010. “Clustering, Spatial Correlations and Randomization Interference." Working Paper 15760, National Bureau of Economic Research, NBER, Cambridge, MA. https://doi.org/10.1080/01621459.2012.682524

Basak, J.K., M.A. Ali, M.N. Islam, and M.A. Rashid. 2010. "Assessment of the Effect of Climate Change on Boro Rice Production in Bangladesh using DSSAT Model." Journal of Civil Engineering (IEB) 38(2): 95-108.

Bernstein, L. 1975. "Effects of salinity and Sodicity on plant growth." Annual Review of Phytopathology 13: 295-312. https://doi.org/10.1146/annurev.py.13.090175.001455

Belotti, F., G. Hughes, and A.P. Mortari. 2014. "XSMLE: Stata Module for Spatial Panel Data Models Estimation." Statistical Software Components.

—. 2016. "Spatial Panel Data Models Using Stata." Research Paper Series, CEIS Working Paper No. 373.

Bhuiyan, Md. J.A.N. and D. Dutta. 2011. "Assessing Impacts of Sea Level Rise on River Salinity in the Gorai River Network, Bangladesh." Estuarine, Coastal and Shelf Science 96(1): 219227. https://doi.org/10.1016/j.ecss.2011.11.005

Brecht, H., S. Dasgupta, B. Laplante, S. Murray, and D. Wheeler. 2012. "Sea-Level Rise and Storm Surges: High Stakes for a Small Number of Developing Countries." The Journal of Environment \& Development 21(1): 120-138.

Cameron, A.C., J.B. Gelbach, and D.L. Miller. 2011. "Robust Inference with Multiway Clustering." Journal of Business \& Economic Statistics 29(2): 238-249. https://doi.org/ $10.1198 /$ jbes.2010.07136

Center for International Earth Science Information Network. 2010. Low-Elevation Coastal Zone (LECZ) Rural-Urban Estimates. http://sedac.ciesin.columbia.edu/gpw/lecz.jsp Accessed March 2017.

Cline, W. 2007. “Global Warming and Agriculture: Impact Estimates by Country." Washington, DC: Center for Global Development and Peterson Institute for International Economics.

Dasgupta, S., M.M. Hossain, M. Huq, and D. Wheeler. 2014. "Climate Change, Soil Salinity and the Economics of High-Yield Rice Production in Coastal Bangladesh." Policy Research Working Paper No. 7140, Development Research Group, World Bank, Washington, DC.

Dasgupta, S., F. A. Kamal, Z.H. Khan, S. Choudhury, and A. Nishat. 2015a. "River Salinity and Climate Change: Evidence from Coastal Bangladesh in Asia and the World Economy Actions on Climate Change by Asian Countries." Edited by John Whalley and Jiahua Pan, World Scientific Press, 205-242.

Dasgupta, S., M. M. Hossain, M. Huq, and D. Wheeler. 2015b. Climate Change and Soil Salinity: The Case of Coastal Bangladesh. Ambio 44(8): 815-826.

Dasgupta, S., B. Laplante, C. Meisner, D. Wheeler, and J. Yan. 2009. “The Impact of Sea Level Rise on Developing Countries: A Comparative Analysis." Climatic Change, 93(3): 379388. https://doi.org/10.1007/s10584-008-9499-5

Efisue, A.A., B.C. Umunna, and J.A. Orluchukwu. 2014. "Effect of Yield Components on Yield Potential of Some Lowland Rice (Oyza sativa L.) in coastal region of Southern Nigeria." Journal of Breeding and Crop Science 6(9): 119-127. https://doi.org/10.5897/ JPBCS2014.0449

Elhorst, P. 2010. Spatial Panel Data Models in Handbook of applied spatial analysis: Software Tools, Methods and Applications. Edited by Fisher, M.M., Getis, A. Springer.

Grattan, S., L. Zeng, and S.M Roberts, 2002. "Rice is More Sensitive to Salinity than Previously Thought." California Agriculture 56(6): 189-198. 
Greenway, H., and R. Munns. 1980. "Mechanisms of Salt Tolerance in Nonhalophytes." Annual Review of Plant Physiology 31:149-190. https://doi.org/10.1146/annurev.pp.31.060180. 001053

Greiner, R., and D. Gregg. 2011. "Farmers' Intrinsic Motivations, Barriers to the Adoption of Conservation Practices and Effectiveness of Policy Instruments: Empirical Evidence from Northern Australia." Land Use Policy 28(1): 257-265. https://doi.org/10.1016/j. landusepol.2010.06.006

Hansen, J.E., and Sato, M. (2012). Paleoclimate Implications for Human-Made Climate Change. In: Berger, A., Mesinger, F., Sijacki, D. (eds) Climate Change. Springer, Vienna

Haque, S.A. 2006. "Salinity Problems and Crop Production in Coastal Regions of Bangladesh." Pakistan Journal of Botany 38(5): 1359-1365.

Hassan, A., and M.A.R. Shah. 2006. "Impact of Sea Level Rise on Suitability of Agriculture and Fisheries." Center for Environmental and Geographic Information Services, Dhaka, Bangladesh.

Government of the People's Republic of Bangladesh, Ministry of Environment and Forest. 2005. National Adaptation Programme of Action. Government of Bangladesh. http:// unfccc.int/resource/docs/napa/ban01.pdf

Hasamuzzaman, M., M. Fujita, M.N. Islam, K.U. Ahamed, and K. Nahar. 2009. "Performance of Four Irrigated Rice Varieties under Different Levels of Salinity Stress." International Journal of Integrative Biology 6(2): 85-90.

Kapoor, M., H.H. Kelejian and I. R. Prucha. 2007. "Panel Data Models with Spatially Correlated Error Components." Journal of Econometrics 140(1): 97-130. https://doi.org/10.1016/j. jeconom.2006.09.004

Karim, Z., S.G. Hussain and M. Ahmed. 1990. "Salinity Problems and Crop Intensification in the Coastal Regions of Bangladesh." Soils publication No. 33. Bangladesh Agricultural Research Council.

Kelejian, H. and I.R. Prucha. 2006. Specification and Estimation of Spatial Autoregressive Models with Autoregressive and Heteroskedastic Disturbances. Department of Economics, University of Maryland. https://doi.org/10.1016/j.jeconom.2009.10.025

Kelejian, H., I.R. Prucha and Y. Yuzefovich. 2004. "Instrumental Variable Estimation of a Spatial Autoregressive Model with Autoregressive Disturbances: Large and Small Sample Results" in Spatial and Spatiotemporal Econometrics, Advances in Econometrics, edited by J. LeSage and R.K. Pace 18: 163-198. New York: Elsevier.

Kelejian, H. and I.R. Prucha. 1998. "A Generalized Spatial Two-Stage Least Squares Procedure for Estimating a Spatial Autoregressive Model with Autoregressive Disturbances." Journal of Real Estate Finance and Economics 17(1): 99-121.

Khatun, S., C.A. Rizzo, and T.J. Flowers. 1995. "Genotypic Variation in the Effect of Salinity on Fertility in Rice." Plant and Soil 173(2): 239-250.

Khatun, S. and T.J. Flowers. 1995. Effects of Salinity on Seed Set in Rice. Plant, Cell \& Environment, 18(1): 61-67. https://doi.org/10.1111/j.1365-3040.1995.tb00544

Lee, L.F. and J. Yu. 2010. "Estimation of Spatial Autoregressive Panel Data Models with Fixed Effects.” Journal of Econometrics 154(2): 165-185. https://doi.org/10.1016/j.jeconom. 2009.08.001

Mahmood, S. M.S., F. Najneen, K.S. Hoque, S. Rahman, and M. Shamim. 2010. “Climate Change: A Study on Impact and People's Perception (A Case Study on Mongla Upazila, Bagerhat District, Bangladesh)." Bangladesh Research Publications Journal 4(2): 153-164.

Margulis, S., G. Hughes, R. Schneider, K. Pandey, U. Narain, and T. Kemeny. 2010. Economics of Adaptation to Climate Change: Synthesis Report. World Bank Climate Change Synthesis Report. World Bank, Washington, DC.

Maniruzzaman, M., et al. 2015. "Climate Change Impacts on Crop Production and Water Requirement in Southern Barisal, Bangladesh" In Revitalizing the Ganges Coastal Zone: Turning Science into Policy and Practices, Conference Proceedings, ed. Humphreys, E. T.P. Tuong, M.C. Buisson, I. Pukinskis, and M. Phillips, 2015, Colombo, Sri Lanka: CGIAR Challenge Program on Water and Food (CPWF). 
Nobi, N., and A. Das Gupta. 1997. "Simulation of Regional Flow and Salinity Intrusion in an Integrated Stream-Aquifer System in Coastal Region: Southwest Region of Bangladesh." Ground Water 35(5): 786-796. https://doi.org/10.1111/j.1745-6584.1997.tb00147

Petersen, L., and S. Shireen. 2001. "Soil and Water Salinity in the Coastal Area of Bangladesh." Bangladesh Soil Resource Development Institute, Dhaka, Bangladesh.

Pfeffer, W.T., J.T. Harper, and S. O'Neel. 2008. “Kinematic Constraints on Glacier Contributions to 21st-Century Sea-Level Rise." Science 321(5894): 1340-1343. https://doi.org/10. 1126/science.1159099

Rahman, M.M. and M. Ahsan. 2001. "Salinity Constraints and Agricultural Productivity in Coastal Saline Area of Bangladesh." Soil Resources in Bangladesh: Assessment and Utilization. Dhaka. Bangladesh.

Rahmstorf, S. 2007. "A Semi-Empirical Approach to Projecting Future Sea-Level Rise." Science, 315(5810): 368-370. https://doi.org/10.1126/science.1135456

Sarker, Md. A.R., K. Alam and J. Gow. 2012. "Exploring the Relationship between Climate Change and Rice Yield in Bangladesh: An Analysis of Time Series Data." Agricultural Systems. 112: 11-16. https://doi.org/10.1016/j.agsy.2012.06.004

Sarwar, Md. G.M. 2005. "Impacts of Sea Level Rise on the Coastal Zone of Bangladesh." Master's Programme in Environmental Science. Lund University, Sweden.

Shahid, S. 2011. "Impact of Climate Change on Irrigation Water Demand of Dry Season Boro Rice in Northwest Bangladesh." Climatic Change 105(3): 433-453. https://doi.org/10. 1007/s10584-010-9895-5

Soil Research Development Institute (SRDI). 1998a. Soil Salinity Map of Bangladesh. 1973. Soil Resources Development Institute, Dhaka. Bangladesh.

— 1998b. Soil Salinity Map of Bangladesh. 1997. Soil Resources Development Institute, Dhaka. Bangladesh.

_ 2000. Soil Salinity in Bangladesh. 2000. Soil Resources Development Institute, Dhaka. Bangladesh.

Soil Research Development Institute. 2010. Saline Soils of Bangladesh. Soil Resources Development Institute, Dhaka. Bangladesh.

Suryanarayanan, S. 2010. Innovations \& Food Security in Bangladesh. Strategic Foresight Group. November. http://www.strategicforesight.com/inner-articles.php?id=122\#.U6BLcvldXh5. Accessed March 2017.

Thomas, T.S., K. Mainuddin, C. Chiang, A. Rahman, A. Haque, N. Islam, S. Quasem, and Y. Sun. 2013. Agriculture and Adaptation in Bangladesh: Current and Projected Impacts of Climate Change (Vol. 1281). International Food Policy Research Institute, Washington DC.

UK DEFR (U.K. Department of Environment, Food and Rural Affairs). 2007. Investigating the Impact of Relative Sea-Level Rise on Coastal Communities and Their Livelihoods in Bangladesh. Dhaka: Institute of Water Modelling in Bangladesh and Center for Environment and Geographic Information Services in Bangladesh.

Vermeer, M. and S. Rahmstorf. 2009. "Global Sea Level Linked to Global Temperature." Proceedings of the National Academy of Sciences 106(51): 21527-21532. https://doi. org/10.1073/pnas.0907765106

Wheeler, D. 2011. "Quantifying Vulnerability to Climate Change: Implications for Adaptation Assistance." Working Paper No. 240, Center for Global Development. Washington DC. https://doi.org/10.2139/ssrn.1824611

World Bank. 2000. “Bangladesh: Climate Change and Sustainable Development.” Report No. 21104-BD. Rural Development Unit, South Asia Region. Washington DC.

World Bank, World Food Programme, and Bangladesh Bureau of Statistics. 2010. "Poverty Maps of Bangladesh - 2010 Technical Report." Technical Report. World Bank. Washington DC. http://hdl.handle.net/10986/20785.

Yoshida, S. 1983. "Rice." In Potential Productivity of Field Crops under Different Environments. Eds WH Smith and Stephen J. Banta. Los Baños, Philippines: International Rice Research Institute. 
Table A1. Soil Salinity by Upazila, 2012 and 2050

\begin{tabular}{|c|c|c|c|c|c|c|}
\hline \multirow[b]{2}{*}{ Region } & \multirow[b]{2}{*}{ District } & \multirow[b]{2}{*}{ Sub-District } & \multirow[b]{2}{*}{ Upazila } & \multicolumn{2}{|c|}{ Soil Salinity (dS/m) } & \multirow[b]{2}{*}{ Change } \\
\hline & & & & 2012 & 2050 & \\
\hline Khulna & Khulna & Khulna & Paikgachha & 15.8 & 16.2 & 0.5 \\
\hline Khulna & Khulna & Shatkhira & Assasuni & 15.8 & 16.2 & 0.5 \\
\hline Khulna & Khulna & Bagerhat & Fakirhat & 13.1 & 15.2 & 2.2 \\
\hline Khulna & Khulna & Khulna & Dacope & 14.1 & 15.2 & 1.1 \\
\hline Khulna & Khulna & Khulna & Dighalia & 13.4 & 14.7 & 1.3 \\
\hline Khulna & Khulna & Khulna & Dumuria & 13.4 & 14.7 & 1.3 \\
\hline Khulna & Khulna & Bagerhat & Rampal & 13.1 & 14.6 & 1.5 \\
\hline Khulna & Khulna & Khulna & Rupsa & 12.6 & 14.2 & 1.6 \\
\hline Khulna & Khulna & Bagerhat & Mollahat & 11.0 & 14.0 & 3.0 \\
\hline Khulna & Khulna & Bagerhat & Bagerhat S. & 10.9 & 13.9 & 3.0 \\
\hline Khulna & Khulna & Khulna & Kotwali & 12.5 & 13.8 & 1.3 \\
\hline Khulna & Khulna & Khulna & Batiaghata & 10.9 & 12.2 & 1.3 \\
\hline Khulna & Khulna & Bagerhat & Chitalmari & 7.3 & 9.1 & 1.7 \\
\hline Khulna & Khulna & Bagerhat & Kachua & 6.8 & 8.3 & 1.6 \\
\hline Khulna & Khulna & Bagerhat & Morrelganj & 6.8 & 7.8 & 1.1 \\
\hline Khulna & Khulna & Shatkhira & Tala & 7.0 & 7.8 & 0.8 \\
\hline Khulna & Khulna & Khulna & Phultala & 6.2 & 7.3 & 1.1 \\
\hline Barisal & Patuakhali & Patuakhali & Kalapara & 4.3 & 5.4 & 1.1 \\
\hline Barisal & Patuakhali & Bhola & Manpura & 3.6 & 4.7 & 1.1 \\
\hline Barisal & Barisal & Pirojpur & Pirojpur S. & 3.7 & 4.7 & 1.0 \\
\hline Barisal & Patuakhali & Bhola & Charfasson & 3.5 & 4.7 & 1.1 \\
\hline
\end{tabular}




\begin{tabular}{|c|c|c|c|c|c|c|}
\hline Chittagong & Noakhali & Noakhali & Begumganj & 3.5 & 4.6 & 1.1 \\
\hline Barisal & Barisal & Pirojpur & Nesarabad & 3.6 & 4.6 & 1.0 \\
\hline Chittagong & Noakhali & Noakhali & Noakhali S. & 3.3 & 4.4 & 1.1 \\
\hline Barisal & Barisal & Pirojpur & Nazirpur & 3.4 & 4.4 & 1.0 \\
\hline Dhaka & Faridpur & Gopalgonj & Tungipara & 3.3 & 4.3 & 1.0 \\
\hline Barisal & Barisal & Barisal & Banaripara & 3.3 & 4.3 & 1.0 \\
\hline Khulna & Khulna & Shatkhira & Kalaroa & 3.0 & 4.0 & 0.9 \\
\hline Khulna & Khulna & Shatkhira & Satkhira S. & 3.0 & 4.0 & 0.9 \\
\hline Khulna & Jessore & Jessore & Keshabpur & 3.0 & 4.0 & 0.9 \\
\hline Barisal & Barisal & Pirojpur & Mathbaria & 2.9 & 3.9 & 1.0 \\
\hline Barisal & Patuakhali & Bhola & Lalmohan & 2.8 & 3.9 & 1.1 \\
\hline Barisal & Patuakhali & Borgona & Bamna & 2.9 & 3.9 & 1.0 \\
\hline Khulna & Khulna & Pirojpur & Mathbaria & 2.9 & 3.9 & 1.0 \\
\hline Barisal & Patuakhali & Borgona & Patharghata & 2.9 & 3.9 & 1.0 \\
\hline Barisal & Patuakhali & Borgona & Amtali & 2.8 & 3.9 & 1.1 \\
\hline Barisal & Barisal & Pirojpur & Kawkhali & 2.7 & 3.7 & 1.0 \\
\hline Barisal & Patuakhali & Borgona & Barguna S. & 2.6 & 3.7 & 1.1 \\
\hline Chittagong & Noakhali & Feni & Daganbhuiyan & 2.5 & 3.6 & 1.1 \\
\hline Chittagong & Noakhali & Noakhali & Senbagh & 2.5 & 3.6 & 1.1 \\
\hline Chittagong & Noakhali & Noakhali & Companiganj & 2.5 & 3.6 & 1.1 \\
\hline Chittagong & Chittagong & Chittagong & Kotwali & 2.2 & 3.3 & 1.0 \\
\hline Chittagong & Chittagong & Chittagong & Anwara & 2.2 & 3.3 & 1.0 \\
\hline Chittagong & Chittagong & Chittagong & Patiya & 2.2 & 3.3 & 1.0 \\
\hline Khulna & Jessore & Jessore & Manirampur & 2.4 & 3.3 & 0.9 \\
\hline
\end{tabular}


Table A1. Continued

\begin{tabular}{|c|c|c|c|c|c|c|}
\hline \multirow[b]{2}{*}{ Region } & \multirow[b]{2}{*}{ District } & \multirow[b]{2}{*}{ Sub-District } & \multirow[b]{2}{*}{ Upazila } & \multicolumn{2}{|c|}{ Soil Salinity (dS/m) } & \multirow[b]{2}{*}{ Change } \\
\hline & & & & 2012 & 2050 & \\
\hline Barisal & Patuakhali & Bhola & Tazumuddin & 2.0 & 3.1 & 1.1 \\
\hline Barisal & Patuakhali & Bhola & Burhanuddin & 2.0 & 3.1 & 1.1 \\
\hline Barisal & Patuakhali & Bhola & Daulatkhan & 2.0 & 3.1 & 1.1 \\
\hline Barisal & Patuakhali & Bhola & Bhola S. & 2.0 & 3.1 & 1.1 \\
\hline Barisal & Barisal & Barisal & Mehendiganj & 2.0 & 3.1 & 1.1 \\
\hline Barisal & Patuakhali & Patuakhali & Bauphal & 1.9 & 3.0 & 1.2 \\
\hline Barisal & Barisal & Pirojpur & Bhandaria & 1.8 & 2.9 & 1.0 \\
\hline Khulna & Jessore & Jessore & Abhaynagar & 2.0 & 2.9 & 0.8 \\
\hline Barisal & Barisal & Barisal & Bakerganj & 1.7 & 2.8 & 1.1 \\
\hline Barisal & Barisal & Jhalakati & Nalchity & 1.7 & 2.8 & 1.1 \\
\hline Barisal & Patuakhali & Patuakhali & Patuakhali S. & 1.7 & 2.8 & 1.1 \\
\hline Barisal & Patuakhali & Patuakhali & Mirzaganj & 1.7 & 2.8 & 1.1 \\
\hline Chittagong & Noakhali & Lakshmipur & Ramgati & 1.6 & 2.7 & 1.1 \\
\hline Khulna & Khulna & Khulna & Terokhada & 1.7 & 2.7 & 1.0 \\
\hline Khulna & Jessore & Narail & Kalia & 1.7 & 2.7 & 1.0 \\
\hline Barisal & Barisal & Jhalakati & Kathalia & 1.5 & 2.6 & 1.0 \\
\hline Barisal & Barisal & Jhalakati & Rajapur & 1.5 & 2.6 & 1.0 \\
\hline Khulna & Jessore & Jessore & Bagherpara & 1.6 & 2.5 & 0.9 \\
\hline Khulna & Jessore & Magura & Shalikha & 1.6 & 2.4 & 0.9 \\
\hline Khulna & Jessore & Narail & Lohagara & 1.4 & 2.4 & 1.0 \\
\hline Dhaka & Faridpur & Gopalgonj & Kashiani & 1.3 & 2.3 & 1.0 \\
\hline
\end{tabular}




\begin{tabular}{|c|c|c|c|c|c|c|}
\hline Dhaka & Faridpur & Gopalgonj & Gopalganj S. & 1.3 & 2.3 & 1.0 \\
\hline Dhaka & Faridpur & Faridpur & Alfadanga & 1.3 & 2.3 & 1.0 \\
\hline Khulna & Jessore & Narail & Narail S. & 1.0 & 1.9 & 0.9 \\
\hline
\end{tabular}

Source: Underlying calculations ofDasgupta et al. $2015 \mathrm{~b}$ 